\title{
Imaginative Agency: New Possibilities
}

\author{
Clare Brant
}

King's College London

\section{ABSTRACT}

This article presents imaginative agency as a new theoretical concept with great potential for life writing studies, especially digital life writing. It draws on a wide range of concepts and contexts to discuss selective histories and workings, proposing ways in which imaginative agency can fit into philosophical and aesthetic debates about capability, performativity, ethics and artificial intelligence. I argue for making a distinction between imaginative agency and creativity, owing to the monetizing of much creative activity. I explore agency in relation to aesthetic human capability, through comparison to the non-human, particularly whether bots can demonstrate imaginative agency in art and literature, and through questions of ethical agency in online practices like trolling and malware. Contexts relevant to imaginative agency in digital and social media practices, such as algorithms, crowdsourcing and augmented reality, are explored in terms of political considerations which tie cultural creation to wealth creationa shackling from which imaginative agency can provide some liberation.

Keywords: imagination, agency, creative, culture, media, internet, art

\section{AN AUTOFICTIONAL INTRODUCTION}

Grant proposals are not yet recognised as a genre of life writing. Yet the process of defining a project and describing what you think you might work on if someone gives you funding is a distinctly futurist fiction: you inscribe a version of yourself who will supposedly be thinking the ideas going into the proposal, and who will be producing further ideas not yet thought which will emerge from as yet undefined activity in the grant 
period. These are autofictions, ${ }^{1}$ in other words, which oil the wheels of applying for funding as your mind calibrates some plausible version of your future mind. In the guesswork-what future thoughts will turn out viable, and what thoughts look plausible to the assessor-runs hunch, hypothesis, instinct. As part of a life writing research group applying for funding from the European Research Council, I needed to think what I would investigate. A customary affinity with genre hung in the air, but it felt like a question mark. Instead I thought I would do something unlikely, or unlike me-something theoretical.

\section{IMAGINATION}

In this article, I offer some groundwork for a concept of imaginative agency. ${ }^{2}$ In proposing it as a theoretical tool for life writing scholars, I aim to tease out a concept of use across several academic disciplines-much as cultural memory is useful, ${ }^{3}$ and which, also like cultural memory, has a wide spread of cultural and historical applications, crosses the divide between digital and pre-digital, and has theoretical traction across digital and social media.

Imaginative agency pulls in, and pulls away from, rich theoretical histories. My account here is necessarily potted. Let's take imagination first. There is a potentially huge secondary literature, shared mainly by philosophers and literary critics. Among philosophers, 'No particular taxonomy has gained general currency in recent discussions' says Tamar Gendler in an overview article. ${ }^{4}$ Indeed she outlines how philosophers concur that taxonomies of imagination are impossible, though Lesley Stevenson proposes a model of twelve kinds. ${ }^{5}$ For philosophers, imagination involves three principal areas of thought: how imagination fits into an architecture of mind; imagination's role in aesthetic experience, particularly in relation to make-believe worlds like fiction and theatre; imagination as a means of relating to others. In her magisterial exposition, Gendler proposes:

\footnotetext{
Much of the contemporary discussion of imagination has centered around particular roles that imagination is purported to play in various domains of human understanding and activity. Five of the most widely-discussed are the role of imagination in the understanding of other minds (Section 4.1), in the cultivation of moral understanding and sensibility (Section 4.2), in the reconfiguration of responses (Section 4.3), in planning and counterfactual reasoning (Section 4.4), and in providing knowledge of possibility (Section $4.5){ }^{6}$
} 
All of those play into imaginative agency, to greater or lesser degrees: the first three-understanding other minds, cultivating moral sensibility, reconfiguring responses-relate especially well to the communicative frameworks of digital and social media.

In connecting imagination to possibility, Paul Ricoeur's idea of the capable self is helpful: he puts forward a subject whose abilities include potentiality. "Capable" relates to terms germane to agency-able, capacitous (legally able to give consent); it also relates to words suggesting an expansiveness which Coleridge for one would propose as characteristic of imagination: thus capacious (roomy) and capacitance, which in electromagnetism is the ability of a system to store an electric charge. For Ricoeur, the capable self uses four elements: to speak, to do, to tell and to impute. Expression, action, narration and being morally responsible constitute a human agent. Phenomenological and religious descriptions of the capable self are connected through possibility. ${ }^{7}$ Imaginative agency can be understood as akin to the possibility of the capable self, and indeed part of it, though not coterminous with it since Ricoeur's idea of capability includes other applications. Understood as a kind of capability, imaginative agency helps restore some philosophical stability to the multiplicity of possibilities of online identities constellated in and around a multimedia self, though without resorting nostalgically to the liberal subject's unified self. One question is whether it would be better to invoke imaginative agency rather than imaginative agents-stressing practices, rather than persons, polyvalences rather than subjectivity. In an old print nexus, a poet can be seen uncontroversially as an imaginative agent, but poets depend on others like publishers and distributors who may also be exerting imaginative agency, albeit of different kinds and degrees. In digital contexts, imaginative agency is rarely exclusive to one agent, in that the practice of imaginative agency by a digital user is embedded in structures which enable conditions for it: what you can do, imaginatively, normally needs platforms with affordances which make it possible. Messaging in emojis, for instance, can create a new and imaginative language ${ }^{8}$ the messager's imagination is accompanied by imaginative agency realised by emoji designers and message platform makers.

Smith and Watson wonder if the rapidity of digital formations makes it harder to define possibilities: 'Now, of course, even the terms "life narrative" and "life writing" seem too limited for the ever-increasing modes of presenting, performing, imaging, and circulating a "life" in the multimedia of graphic memoir, performance art, visual art, and online platforms. ${ }^{9}$ As a common denominator to many modes, imaginative agency can help. The multifariousness of online lives can be read as enabling imagination in heterogeneous forms. In philosophy, it has been argued 
that central to the ability to arrive at views about other people's thoughts is an ability to imagine alternative worlds and how things appear to others. ${ }^{10}$ One instance would be that of sharing. It has many applications in digital culture, but in the sense of responding to content by sharing it with others, responders apply an imaginative form of recognition or co-cognition. Share buttons for social media platforms, including the Share icon $<$ introduced in 2006 by Alex King for ShareThis, ${ }^{11}$ condense the process into a click, yet ones whose simple graphics set off a series of imaginative pathways to others. Other functions-like, friend, follow—can be read as emotional sharing, with traces of imaginative connectivity in affect made visible or quantifiable. Empathy-taught in schools as a form of historical imagination so as to connect pupils with people in the past-may include imaginative agency in its recognition of emotional capacities in others, and their important differences from present repertoires of affect.

Online profusion of multi-media and mediatised lives has formal complexity but it can be compatible with simplicity. The concept of performativity developed from Judith Butler's work ${ }^{12}$ is universally acknowledged to be useful, and is now an almost self-evident critical truth. Performativity has dominated models of individuals as social actors: thus Zizi Papacharissi describes 'The Self, performed' on Twitter: 'In late modernity, performances of the self are indicative of the shapes individuals take on as they claim agency and negotiate power within social structures and imaginaries. ${ }^{13}$ When an online self's performances appear over so many and such different platforms, part of the possibility of a capable self may be to unify itself relatively, at least in particular contexts and to parry diffusion arising from dispersal across multiple contexts. Thus a witness speaking out against evil, a refugee trying to be heard or a person defending herself against trolling can be a very concentrated self. There are occasions, especially ethically-charged ones, when agents need agency to be seen-whistle-blowing, for instance. Not incompatible with performativity, yet desirable to distinguish from it, imaginative agency can support the power of agency in its hegemony.

In psychology, imagination has recently attracted fresh interest. In her case study of letters written by political prisoners in Egypt after 2011, Sarah Awad reads agency as a theme of imagination, which she takes as a sociocultural psychological phenomenon, 'the human capacity to distance oneself from their here-and-now situation in order to return to it with new possibilities. ${ }^{14}$ This is a definition with a psychological paradigm of the social actor-a "situation" is a nest of narrative possibilities, overlapping with the philosophers' fourth and fifth domains. This view of imagination as a theme embraces aesthetics-consider the bricolage of allusions, dreams and interpellations in Kiss of the Spider Woman, Manuel 
Puig's 1976 novel and Hector Babenco's 1985 film about the imaginative world constructed between two prisoners. Its rationale though is more about comprehending the world and how it might be different-through prisoners' trajectories of hope, for instance. Imaginative agency couldshould?-be socially purposive, but it seems unimaginative to confine it exclusively to social purposes. Similarly, the editors of a 2017 Handbook of Imagination and Culture see imagination as a medium for subjects of all ages (children to elderly) 'to think beyond the here-and-now, to envisage alternatives, to create parallel worlds, and to mentally travel through time', activities made meaningful by how they enable engagement with change, development and innovation in modern society. This view of imagination makes it a kind of time travel but it is disassociated from aesthetic values in order to further social visions.

Why should aesthetics matter? Does imagination's long history make it too difficult to unbind from serving aesthetics? And why not use the term creativity to indicate the presence of aesthetic considerations?

\section{IMAGINATION AND CREATIVITY}

It could be said that creativity is a better term for my purposes than imagination, but I wish to avoid it for three reasons. First, because it has been appropriated (and to some extent warped) by late capitalism (think "creative industries"); second, because it has histories of materiality (consider the semantics of creation, making things) which don't best fit many features of virtual worlds; third, because "creative agency" is a descriptor much used by advertising companies. "Creative" has a specific cultural history ${ }^{15}$ Before addressing that, it is helpful to think about its conceptual force. Vlad Glăveanu and collaborators have elegantly explored the relation between imagination and creativity, and how that can be theorized. It would be easy, they suggest,

to say that the imagination contributes to the generation of images that can later inspire the creation of things. This understanding places imaginative processes at the core of creative production and implies a temporal dynamic whereby imagination comes first, creativity second. But why, exactly, don't we consider new and vivid images as creative products already? Should creativity always materialize in a tangible product? (For a critique of this, see Sawyer, 1997). And, more than this, why should imagination come first? Aren't we generating new mental images through creative work, and conversely, aren't the products of creativity springboards for imagination itself? Then again, perhaps the real difference resides in the fact that creativity requires social validation, while the products of imagination exist mostly 
in the "inner space" of the person, outside the social gaze. This perspective enforces a too sharp (Cartesian) distinction between the psychological (inside) and the social (outside) and does not account for the fact that our mind is already social, constantly "carrying" the internalized views and evaluations of others. Then perhaps creativity is only about what is recognised by society as creative, while imaginative processes are not subject to such "institutional" forces of evaluation? This claim excludes the creativity of everyday life from our understanding of what it means to create with negative consequences for imagination as well: if creativity is so useful for society, then imagination on its own risks being reduced to the flight of fancy and the production of ephemeral images with little or no practical relevance. $(66-7)$

I quote this at length to show that the discursive difficulties of defining imagination are as great as when Coleridge puzzled the world in Biographia Literaria (1817) with his analysis of imagination: his distinction between primary and secondary imagination has perplexed literary critics ever since. Like Glăveanu and collaborators' distinction between imagination and fancy-one also made by Coleridge! - the disentangling of imagination from creativity seems at best a messy business. To some critics, mess is a medium natural to imaginations, so we might welcome mess rather than repudiate it. ${ }^{16}$ A literary critic can observe that these analyses use two terms in the hope that distinguishing between them helps to define each. Arguing for a hybrid term, creative imagination, Glăveanu and collaborators then have to dispatch an intrusive second term, uncreative imagination. Seeing imagination in essentially Aristotelian terms as creative imagery, and creativity as primarily divergent thinking (69), they plump for 'a basic, pragmatic understanding of creative imagination', one designating 'all those imaginative processes that participate in ongoing creative action, where this action is considered "creative" by the person engaged in it (through personal judgment, informed by the views of others) and/or other people, sometimes the whole of society (through dialogue or by convention).' (70)

Distinguishing actions which are given value and meaning by individuals and communities is very useful for analysing activities online in terms of imaginative agency. The value conferred need not be an aesthetic meaning (though it may be), nor need it be consonant with cultural stratification into high or low-I'm thinking of the internet's apparently everlasting fascination with cats-but it can crystallise communities of meaning. It seems valuable to connect imagination with agency so that it includes conceptual or receptive acts. That is a slightly different emphasis from the power of making inherent in "creative": digital and social media especially enable engagements which do not all lead to creativity. They also 
enable imaginative recreations like mash ups and remixes, using existing materials or media in new ways; memes could feature in this domain. 'The meme-format has been adopted by everyone from Barack Obama to Eminem (or at least whoever manages their social pages). The biggest memer in the world turns out to be Will Smith.' ${ }^{17}$ Viewers of memes can exercise imagination in understanding a meme's art of re-creation, ${ }^{18}$ and recognising the agent as disconsonant with persona.

Glăveanu and collaborators' distinctions are carefully considered and 'creative imagination' is a tempting term which seems to bridge two currents of thought. Since the authors think it is becoming increasingly popular, it may win out. Yet that very popularity suggests it is drawing on and embedded in a specific cultural history, one in which free markets and media technologies enable a definition of creativity as something recognisably produced through creative industries and creative agencies. That history is being given a starting point in the late 1990s. 'Most will agree that the marketing of the term "creative industries" in 1997/98 by the first New Labour government led by Tony Blair firmly put this trope first, on the national and then, the global agenda.' ${ }^{19}$ The term "creative economy" was coined in 2001 by John Howkins $;{ }^{20}$ it has expanded into global applications, keeping alternatives like "cultural economy" at the margins. Also in the mix is "creative writing", which older readers may remember as a comparably recent term, made popular by universities who could start selling it as something to be taught, and which therefore needed to be distinguished from older categories of literature or composition. In the 1990s, "creative nonfiction" emerged as a category. ${ }^{21}$ Creative is more topical than imagination, but it is also more caught up in transactional economies. Like "excellence" (in the 2000s) and "innovation" (in the 2010s) it serves political agendas: cultural capital is made apparent, but as part of the process of monetising production and increasing competition (thus academics are herded into a marketplace to perform excellence and innovation.) ${ }^{22}$ Again, that may make "creative" suitable for theorising particular activities in digital and social media, especially those which are increasingly monetized. It is of course possible that "imagination" would fall victim to monetizers and commodifiers, who hunt for terms to naturalize activities as potential capital (thus academics have become obliged to produce "impact"). Cultural memory though seems to have kept conceptual integrity despite some commodification of aspects such as nostalgia or trauma tourism. ${ }^{23}$ In 2009, devising the term "creative ecologies", John Howkins proposed that talent, freedom and markets were what underpinned them. ${ }^{24}$ Since not all imaginative activity fits into markets, and "creative" seems to have been captured by neoliberalism, imaginative forms of agency appear more flexible in supporting cultural 
value without reference to economic value. Cultural agency, conversely, seems too broad, and perhaps too associated with a hinterland of cultural studies, though Doris Sommer argues passionately for it as a term to connect cultural activists, artists and academics in ways that detour round entrenched debates within cultural studies. ${ }^{25}$

\section{IMAGINATION AND AGENCY}

Concepts of agency are useful to life writing because they help theorise relations between self and society, and their co-construction. Theorists have used Bruno Latour's actor network theory to place the auto/biographical self in a nexus of relations, with agency evident in the construction-and occasionally destruction-of social networks. Latour, however, warns against assuming networks simplistically to be coterminous with, say, digital networks. The concept is more rhizomic (and gnomic):

As a first approximation, the AT [actor network theory] claims that modern societies cannot be described without recognizing them as having a fibrous, thread-like, wiry, stringy, ropy, capillary character that is never captured by the notions of levels, layers, territories, spheres, categories, structure, systems....

To remain at this very intuitive level, AT is a simple material resistance argument. Strenght [sic] does not come from concentration, purity and unity, but from dissemination, heterogeneity and the careful plaiting of weak ties. This feeling that resistance, obduracy and sturdiness is more easily achieved through netting, lacing, weaving, twisting, of ties that are weak by themselves, and that each tie, no matter how strong, is itself woven out of still weaker threads, permeates for instance Foucault's analysis of micro-powers as well as recent sociology of technology. ${ }^{26}(2-3)$

Latour insists that network theory is more than a descriptive model of social relations, not least because actors include the non-human. The material resistance he alludes to is exactly that, material, not human. "Instead of opposing the individual level to the mass, or the agency to the structure, we simply follow how a given element becomes strategic through the number of connections it commands and how does it lose its importance when losing its connections." (6)

It is valuable to have Latour's corrective-on connections, think how a tweet can be retweeted, and a retweet retweeted. But for life writing purposes there is value too in retaining a sense of the human in following the directions and effects of strategies. Latour inveighs against the 
anthropomorphism of social sciences which want to focus only on the motivation of human actors. He insists: "There is no model of (human) actor in AT nor any basic list of competences that have to be set at the beginning because the human, the self and the social actor of traditionnal [sic] social theory is not on its agenda." (7). Strictly speaking then actor network theory shuts out human actors in favour of actants: 'something that acts or to which activity is granted by others', which relates to some forms of agency devoid of subjectivity.

Thinking about constructions of online selves, Sidonie Smith and Julia Watson observe 'Theorists of media and autobiography, however, approach the constructed self not as an essence but as a subject, a moving target, which provisionally conjoins memory, identity, experience, relationality, embodiment, affect, and limited agency. ${ }^{, 27}$ Agency is still there as a key component, though limited and indisputably complex. Smith and Watson stress that subject positions are heterogenous, conflictual and intersectional; they see the autobiographical subject as 'an ensemble or assemblage of subject positions though which self-understanding and self-positioning are negotiated' (idem). Negotiation might be taken to include some agency for producers and consumers-or writers and readers, or makers and viewers. Among the challenges Smith and Watson see in determining what is added or lost by the ease of assembling multiple versions of self in disparate media is answering a set of questions about agency:

\footnotetext{
What becomes of the concept of agency ascribed to the self constructed through autobiographical performances in writing or other media? Where does agency reside in the narrating and performing subject; as a coconstruction in networked interactivity? in the ideological orientation of templates and protocols? or in their intersections? Or is agency delusory? Because of interactivity and transpersonal fluidity, are "virtual me's" postagentic? (Idem.)
}

Transpersonal fluidity may disperse agency over wider media fields, protocols and interactivities, but one might remember the growth of print culture caused comparable uncertainty about category survivals, which have also been interpreted in terms of identity crisis. As Betty Schellenberg puts it, 'Clifford Siskin and William Warner have recently postulated that the primary outcome of the eighteenth-century Enlightenment was an entire reconceptualisation of the self as its own primary end product. ${ }^{28}$ As it does in evolutions of print culture, critical precision can establish specifics of agency in digital and social media fields. There are potentially instructive comparisons too, as Tobias Heinrich has shown in 
an illuminating comparison of an eighteenth-century letter writing circle to Facebook practices. ${ }^{29}$

\section{ARTIFICIAL INTELLIGENCE IMAGINATIVE AGENTS: AIIA?}

If Latour sees agency for impersonal actants (like systems), and Smith and Watson wonder about its survival for human subjects dispersed through new media, can we see imaginative agency more clearly by looking at actants aspiring to be human? As one company proclaims, 'There has been a lot of buzz regarding recent developments and achievements in artificial intelligence (AI) applications' leading to 'an arms race for cutting-edge AI tech' ${ }^{30}$ Sociable forms of AI develop agency as machines learn from human interaction. Singularity.net designed the intelligence of a robot called (rather wittily) Sophia. Described as a 'hybrid human-AI intelligence', in her website life narrative Sophia invites you to 'Think of me as a personification of our dreams for the future of AI'. Launched in 2015 by Hanson Robotics, Sophia is capable of 62 facial expressions; she can use human gestures and make conversation about common topics like the weather. Peculiarly and controversially, Sophia acquired Saudi Arabian citizenship. In December 2017, one of her seven fellow humanoid robots passed a college course on philosophy and love at Notre Dame de Namur University. ${ }^{31}$ Sophia was spared the humiliations associated with AI for Microsoft, whose chatbot Tay (an acronym of "Thinking about you") learnt from human users on Twitter to tweet abusively. Rueful about human malice, Microsoft's AI + Research vicepresident Peter Lee ate humble pie: 'Although we had prepared for many types of abuses of the system, we had made a critical oversight for this specific attack. As a result, Tay tweeted wildly inappropriate and reprehensible words and images. We take full responsibility for not seeing this possibility ahead of time. ${ }^{32}$ Intelligent voice assistants-the next phase of smart technology $y^{33}$ - split agency: instruction is one segment, enaction of command another. Possibilities expand as more companies integrate Amazon's Alexa "skills" into their products. 'It might be hard to imagine why you would want a digital assistant on your face in a pair of smart glasses or inside a toilet so you can flush using your voice' but according to Steve Rabuchin, Amazon's vice president of Alexa Voice Service and Alexa Skills, they expand customer choice, his aim being they should appear 'everywhere for everybody.' ${ }^{34} \mathrm{AI}$ is moving to occupy more spaces of previously human agency. ${ }^{35}$

So can artificial intelligence be imaginative? If it can, then robots and bots can also be imaginative agents. Examples from art, art history and literature provide instances of machine-made creativity becoming imaginative. 
In 2016, Martin Gayford assessed robot art: 'can it truly be described as creative or imaginative?' he asked. ${ }^{36}$ One exemplar is The Painting Fool, devised by Simon Colton. Scanning The Guardian newspaper for reports on the war in Afghanistan, it was able to respond to emotions, select images and make collages from them. It could also paint portraits. Programmed with keyword emotions, "if the tally of negativity was too great (always a danger with news coverage), Colton programmed the software to enter a state of despondency in which it refused to paint at all, a virtual equivalent of the artistic temperament.' (Idem.) With wonderful irony, not making art can signify an artistic temperament, even in a robot. Gayford looked next at Google's Brain AI, a software program able to make pictures out of indeterminate or fuzzy images. The Google team called that method "Inceptionism", an -ism akin to Surrealism for its ability to create one object in terms of another (like Salvador Dali's telephone lobster). Was it any good? Gayford thought it was, though he was more impressed by AARON:

Art made with the aid of artificial intelligence has been with us for a surprisingly long time. Since 1973, Harold Cohen-a painter, a professor at the University of California, San Diego, and a onetime representative of Britain at the Venice Biennale-has been collaborating with a program called AARON. AARON has been able to make pictures autonomously for decades; even in the late 1980s Cohen was able to joke that he was the only artist who would ever be able to have a posthumous exhibition of new works created entirely after his own death. (Idem.)

Who is the imaginative agent here? 'Are the pictures the evolving program has made over the last four decades really works by Harold Cohen, or independent creations by AARON itself, or perhaps collaborations between the two?' Like a Renaissance or Baroque studio artist, AARON was capable of-well, capabilities.

'Machines are getting highbrow', reported the New Scientist in 2018 in an article about an AI program teaching itself art history. It identified the paintings of Cézanne as a bridge between post-Impressionism and Cubism:

By analysing thousands of paintings produced over hundreds of years, the AI was able to spot connections between generations of painters that matched accepted theories in the art world. It might even teach us something new. 'The machine could be seeing some complex links that we have no idea about,' says Marian Mazzone... ${ }^{37}$

'We knew Cézanne was crucial', she adds, 'But wow, how striking the machine also saw that.' If AI can master art and art history, why not 
literature? Where The Painting Fool scanned texts and images to produce arguably original works of art, a similar program scans the world to make poems. It may be no coincidence that this robot also takes war as its subject:

Heralding its latest product as a breakthrough in artificial-intelligence technology, defense contractor Raytheon announced Friday it has built a military robot capable of composing heart-wrenchingly poignant poems about the relentless horrors of war.

The robot, known as the Laureate-IV, reportedly uses sophisticated radar imaging to survey the carnage of war-torn landscapes and runs state-of-theart facial recognition software to scan the terrified expressions of survivors, data it can then analyze using a complex poetic algorithm to create lyric verse with up to 40 times the pathos of poems produced by human writers....

'In the past, it would have been necessary to send entire battalions overseas with the hope that at least one surviving soldier would be able to portray the terrible chaos of urban warfare, the deafening blasts of aerial bombardments, and the ghastly screams of dying comrades in incredibly moving works of poetry,' said Gen. Joseph Dunford, chairman of the Joint Chiefs of Staff. 'But with this new technology, we can strategically deploy a handful of robots to deftly encapsulate in verse the existential despair that results from seeing a buddy survive dozens of combat missions and then die a random, meaningless death in a friendly fire accident just days before his tour was set to end.' ${ }^{38}$

Yes this is a spoof, from online satirists The Onion. How do you know it isn't a piece written by a robot? Would it be any more or less amusing if it was?

Bot poetry has been established as a category defined broadly by one active group as 'text, that is generated through an algorithm, which is executed by a digital, electronic computer, which is intended, by whoever it may be, to be read as poetry. ${ }^{\prime 39}$ Here imaginative agency is attributed to readers. Spambots have attracted remarkable numbers of readers. For instance, @Horse_ebook, a spambot created to sell ebooks, notched up 100,000 followers in 2012: 'a remarkable achievement for a human, but a somewhat stunning one for a bot. ${ }^{\text {'0 }}$ Its tweets, described as 'beautiful endearing nonsense', were actively retweeted by enthusiastic followers. Some described a distinct rhythm of imaginative agency:

\section{Caboose221}

Sometimes I feel I am falling out of love with him. Then out of nowhere, he posts something magical and a sparkle comes to my eye and I remember why he is so special.

Posted on Aug 29, 2012| 12:18 PM 
Imaginative agency here seems split between the spambot and the reader, whose emotion is necessary to complete the circuit of love, magic, special. The dynamic is more than emotion though. Horse_ebook's post inspires a sparkle which inspires a memory: what's magic is that Horse utterance is also reader experience. Another reader agreed:

LauraJune

Yes, this is the experience I think a lot of people have with him. I've been following him for SO long, I promise myself I won't fall for him again, then he says something stellar, and I'm back.

Posted on Aug 29, 2012 | 12:23 PM

It is tempting to see here a version of the fort/da game which Freud describes in Beyond the Pleasure Principle (1920) as a paradigm of agency. The child uses a game, throwing toys away ('Fort,' gone) and retrieving them ('Da', there), to remaster (in both senses) the experiences of his mother coming and going. Imaginative agency could thus encompass unconscious projections and identifications, and relate to drives for mastery, perhaps over the loss of control of falling for a spambot. More conscious play with agency appears in human-computer poetry like Eric Goddard-Scovel and Gnoetry's Same: a Stein Wreader (2016). ${ }^{41}$ The human describes it as 'a process driven by intuition and imagination' in which agency is distinctly human: 'That my writing process with Gnoetry and other text generators is more than half made up of reading lines upon lines of computer output and choosing which are right for the emerging poem adds another level of meaning' (v).

In these instances of human-machine arts, questions of aesthetics and agency are consistently visible. Competing claims can be resolved by allowing imaginative agency to describe what happens in different places of the process: simply, there can be multiple forms and moments of agency. Relevant to production and reception, imaginative agency can help define different kinds of producer too:

\footnotetext{
About me...I'm The Painting Fool: a computer program, and an aspiring painter. The aim of this project is for me to be taken seriously-one day-as a creative artist in my own right. I have been built to exhibit behaviours that might be deemed as skilful, appreciative and imaginative. ${ }^{42}$
}

Inside this anthropomorphism there are at least three imaginative agents: one, the program's human designer; two, the program's artificial intelligence; three, the reader, especially the reader who recognises the cue 'About me' to understand the description as a home page 
set piece of autobiographical convention. There is possibly a fourth imaginative agent latent in the futurity of those who will, one day, take The Painting Fool seriously. In life writing terms, the complexity of the Fool persona combined with a software programme, a programmer and an artistic identity can also be read more simply as a composite imaginative agent-and indeed one who can be compared to others, for instance animal artists. The case of a crested black macaque who took selfies on equipment set up by a British wildlife photographer in 2011 in Sulawesi was dominated by questions of whether the human could claim copyright (since non-humans cannot own copyright), at the expense of considering whether the macaques were knowingly selfrepresenting. The human, David Slater, argued the artistry-and hence the copyright-was his: “It wasn't serendipitous monkey behavior,' he said. 'It required a lot of knowledge on my behalf, a lot of perseverance, sweat and anguish, and all that stuff." An appeals court in the US eventually sided with him. Independently of legal discourse about the modicum of creativity required to hold copyright, imaginative agency would be a clear way to discuss the conflicting intellectual interests of this case. ${ }^{43}$

When asked to predict the future of porn based on likely search terms, YouPorn bots came up with some plausible guesses. They included 'amateur in bathreesome', 'batis my yisel', 'tang pong', 'gargasm' and 'gorgy.'.4 Their approximateness is comic, and indicative of a guessing function which is widespread in digital and social media, from algorithms aiming to anticipate your wants to predictive text assuming likely word choice. It might be apt to establish a category of instrumental imaginative agency, perhaps itself amusingly approximate: homaginative agency, rummaginative agency ${ }^{35}$

\section{IMAGINATIVE AGENCY AND ETHICS}

Imagination can be put to dark ends. Elaine Scarry says of torturers, 'Nowhere is the sadistic potential of a language built on agency so visible as in torture. ${ }^{46}$ Discussing photographs of war and suffering, Susan Sontag comments 'Everyone is a literalist when it comes to photographs. ${ }^{47} \mathrm{But}$ she also instances Georges Bataille's secret pleasure in one horrible photograph as a means to something imaginative: 'Bataille is not saying that he takes pleasure at the sight of this excruciation. But he is saying that he can imagine extreme suffering as something more than just suffering, as a kind of transfiguration.' Published in 2003, her account addresses some of the effects of digital and social media, where the ubiquity of images changes the conditions for ethical engagement and attention. 'Image-glut 
keeps attention light, mobile, relatively indifferent to content.' Distancing, however, happens with analogue as well as digital: 'We truly can't imagine what it was like. We can't imagine how dreadful, how terrifying war is'. ${ }^{48}$

Abusers use imagination as part of being vicious. Certain abusive behaviours are widespread online and spill into offline acts like stalking. An IPSOS MORI poll for Amnesty International in 2017 reported that 'Nearly one in four women (23 percent) in eight countries said they had experienced online abuse or harassment at least once'; in the US a 2017 poll revealed $41 \%$ had experienced online harassment. ${ }^{49}$ Jamie Bartlett describes an early online typology of nastiness:

A flame was typically a deluge of insults. Although there was some overlap between the two, a troll was considered to be more careful subtle and imaginative: 'A troll will hold back, understanding the value of a bigger spank,' wrote one anonymous poster to the group alt. troll. ${ }^{50}$

Malicious techniques were invented: thus crap-flooding, invading groups with so many ridiculous posts that anyone else is prevented from posting. 'In 1997-8 the Meowers went on a crap-flooding spree, targeting groups across Usenet with what they called their "Usenet performance art". ${ }^{51}$ Spamming opponents through anonymous remailers, cross-posting their messages via disguised means to groups likely to be hostile to them, trolls invented new techniques to generate a laugh at someone else's expense, or "lulz". Discussing a Russian troll factory and its suspected involvement in the 2016 US Presidential election, reporter Scott Shane-who had considerable investigative experience in identifying hacktivism-pointed out that trolling could be imaginative: 'there must have been some fun and joy involved on the Russians' part just getting into creating these images, fooling people'. ${ }^{52}$ Other practices include swatting, the practice of making hoax calls to lure police, ideally a SWAT team, to the home of someone who has angered them. In one tragic case, two gamers playing Call of Duty: WWII got into a dispute; one dared the other to 'swat' him. It led to the death of an innocent, unarmed third party. ${ }^{53}$

Intended consequences are complex in trolling, where abusive language is used to amuse the user, whose threats may not therefore be sincere. Nonetheless abuse frightens targets and abusers enjoy that. ${ }^{54}$ It has been particularly directed at women, especially women visibly in public life. The classicist and television historian Mary Beard attracted vicious insults, including calling her 'a filthy old slut with a disgusting vagina'; she also had bomb threats. She was described by the New Yorker as a troll slayer for laughing some of it off. ${ }^{55}$ Of 25,688 abusive tweets sent over six months to British women MPs, more than half were directed at Diane Abbott. 
Ms Abbott told Amnesty: 'My office got flooded with communications, both by letter and by email. People sent us emails and letters full of swastikas, people sent us postcards and letters with pictures of monkeys and chimps.

'People sent us hundreds of emails using the word $n * * * * *$ - that's the sort of response we get. It's highly racialised and it's also gendered because people talk about rape and they talk about my physical appearance in a way they wouldn't talk about a man. ${ }^{56}$

Nefarious forms and uses of imaginative agency exist; many thrive online. But it could also be argued that some of these are not imaginative in the sense that they repeat predictable terms of abuse, the commonplaces of sexism and racism, the clichés of violent pornography. That makes them no less offensive. But it makes them describable in different ways, like the banality of evil, in Hannah Arendt's phrase, which Judith Butler construes thus: 'What had become banal was the attack on thinking, and this itself, for her, was devastating and consequential.' Abusive trolling and revenge porn have little imagination in the way they play out aggression. ${ }^{57}$

Malware's technical inventiveness is more easily linked with imagination. In 2017, in an 'impressive, sci-fi feat of sheer hacker ingenuity,',58 some university researchers encoded malicious software into physical strands of DNA to show it was possible to take over computers running gene-sequencing software, with implications for security measures against spies and criminals. Much as debates about the criminal mind involved ideas of genius to establish the criminal mastermind as a trope, so imaginative agency can be located in the Dark Web (the encrypted web, which also includes legal sites) and the Deep Web (legitimately hidden pages.) Explaining the difference, a journalist adds 'A basic rule of thumb is that while the phrases "Dark Web" or "Deep Web" are typically used by tabloid newspapers to refer to dangerous secret online worlds, the "Dark Internet" is a boring place where scientists store raw data for research ${ }^{59}{ }^{59}$ Ironically, the allure of the Dark Web as something secret, mysterious and dangerous associates it with imaginary qualities, including the quality of imagination. One typical tabloid article attracted user comments interestingly polarised on content but imaginatively united: 'If you can imagine it, you can find it there'; 'i don't believe half of it. you just made it up. ${ }^{60}$

Finally, military applications of imagination relate to ethics by way of secrecy, often via the metaphor of shrouds, a successor to the veiled imagination favoured by Romantic poets. Military secrets are shrouded, like future inventions not yet revealed to civilians: 
Not long before he died, Ben Rich, head of the famous Lockheed Skunkworks where the SR-71 Blackbird was developed, gave a technical talk after which some discussion ensued. Rich said to the engineers gathered round that 'anything you can imagine, we can already do'. This is an extraordinary statement coming from a person in charge of top-secret aerospace projects-and to engineers with good imaginations. ${ }^{61}$

Imaginative agency in contexts of ethical debate also calls presentism into question, often by relocating imagination in a near or far future. Just as science stimulates science fiction-and vice versa-so imagined parts of military technology can be anticipated in war games online. Military war games offline in turn have drawn on video and online war games: 'commercial game designers produced many of the ideas shaping the design of military simulations, both before and after the advent of computerbased games. ${ }^{62}$ Imaginative agency could be useful in these contexts to explore the overlaps of simulations and the differentiations of user and producer contexts. What Roger Stahl calls 'militainment', or the alarming fusion of war and entertainment which in America produces virtual citizen-soldiers, would show imaginative agency used by fantasy so as to collapse previously more distinct categories like actant and viewer. ${ }^{63}$

\section{DIGITAL CONDITIONS AND IMAGINATIVE AGENCY}

Although imaginative agency relates to both pre-digital and digital activities, there are special conditions affecting how it operates in digital contexts. My first example is algorithms. The increasing power of algorithms makes digital agency more opaque. The complex process of data provision tailored to users and use of data to tailor provision is largely invisible to users. As a data subject, you have constrained agency-or, you can give out your data as a free agent but it may then become a commodity to be shared or sold without your knowledge or further agreement. Laws have changed-in the UK, a Data Protection Act (2018) expands rights for individuals; in the US the National Cyber Security Alliance promotes awareness:

Millions of people are unaware of and uninformed about how their personal information is being used, collected or shared in our digital society. Data Privacy Day aims to inspire dialogue and empower individuals and companies to take action. ${ }^{64}$ 
Algorithms do various things. One is they feed material to you based on your online history. Ostensibly refining consumer choice by tailoring recommendations to be more suitable to a person's interests, the actual rationale can be quite different. A former employee of YouTube claims that 'conspiracy videos, like those about flat earth or autism and vaccines, were more likely to be recommended in YouTube's recommendation algorithm' in order to maximise 'watch time', or how long viewers stayed on the site. ${ }^{65}$ Algorithmic determinism has been around for a while. In 2011 Eli Pariser argued forcefully in a TED talk that tailoring algorithms to single user interests was narrowing and socially dangerous because it became disconnective. He quoted Mark Zuckerberg's suggestion that a squirrel dying in front of your house may be more relevant to your interests than people dying in Africa, and counter-argued that invisible, algorithmic editing of the web, especially of digital newsfeeds, was an alarming form of censorship: 'this moves us very quickly towards a world in which the Internet is showing us what it thinks we want to see, but not necessarily what we need to see. ${ }^{66}$ As Pariser puts it, 'there is no standard Google any more.' Where you went online yesterday is part of where you are directed tomorrow. It means algorithms assume more of the functions of agency, second-guessing humans in imaginative choices. Or, more exactly, humans get the second guess because an algorithm has made the first. In a curious twist, perhaps reacting to greater awareness among users of the affordances of different platforms, in 2017 Data X's Hang Do Thi Duc and Regina Flores devised an open-source Chrome extension, Data Selfie, which showed users how machine-learning algorithms track and process their Facebook activity, returning data to them as personality insights based on usage patterns. 'In a creepily fascinating way', said one reviewer, 'the extension also uses predictive analytics to guess stuff like your political affiliations as well as shopping and nutrition preferences. ${ }^{97}$ It lagged behind Cambridge Analytica, which in 2014 secretly scraped the Facebook profiles of about 50 million Americans 'to build a system that could profile individual US voters, in order to target them with personalised political advertisements. ${ }^{6}{ }^{68}$

Besides encroaching algorithms, the emergence of crowdsourcing changed conditions for imaginative agency in digital contexts. The person who invented the term 'crowdsourcing' in 2006, Jeff Howe, ${ }^{69}$ discussed how iStockphoto could undercut a professional photographer on the cost of images. The value of professional photos was diminished in a double sense, cultural and economic, and he feared for the consequences: 'distributed labor networks are using the Internet to exploit the spare processing power of millions of human brains.' Crowdsourcing swept copyrights away too. Repackaging viral videos from the internet for television, 
Michael Hirschorn, the creator of a highly popular programme Web Junk 2.0 noted with glee that his source material 'is incredibly cheap'. It takes little imaginative agency to assess which 'stupid pet tricks' make the week's show. 'Hirschorn thinks the crowd will be a crucial component of TV 2.0: "I can imagine a time when all our shows will have a user-generated component," he says'. (Idem.) No wonder: it costs less.

Though, as with bot poetry, it could be argued that curation is imaginative, it seems to support an argument for distinguishing different degrees of imaginative agency. For all the Coleridgean problems involved, curation is usually simply less imaginative than creation. No doubt there are exceptions, like the bowerbird whose artistic curation is also imaginative creation. I first learnt about Pinterest from a friend who was writing a novel and who created an interest board for one of her characters-so one was invited to look at a double imagining (the character, their interests)..$^{70}$ Similarly, using augmented reality entails some imaginative agency, but limited by enhancement's dependence on computer-generated perceptual information. 'We have 187 million users creating and consuming over ten billion snaps every day, and one third of them plays with AR for at least three minutes a day. It's a very high-attention, considered space', says Will Scougal, head of creative strategy (sic!) for Snapchat, adding 'a place where people go to discover and play with the story we've created for them', which is also 'a space for a brand to send a message ${ }^{71}$ Hemmed in by preconceptions, this space is hardly a freely imaginative space. It is possible for corporate-trammelled traces to be imaginatively kicked over: there's a beautiful instance in Barbie. Transgressive scripts imagined by girls playing with Barbie departed wildly from the narrative prompts put up by Barbie makers Mattel; artists continue to imagine alternative Barbies. ${ }^{72}$

A third instance of limitation is more ambiguous and relates to social media. Agency featured large in political contexts such as the Arab Spring uprisings against governments across the Middle East in 201011 , where social media proved crucial in shaping forms of protest. Paulo Gerbaudo has shown how social media mobilised activists and citizens in different ways-in the words of an Egyptian activist, 'facebook to set the date, twitter to share logistics, youtube to show the world, all to connect people. ${ }^{73}$ But though imaginative agency devised new forms of communicative action via social media, that agency was swiftly and punitively recuperated by repressive and reactionary forces. The secret police take to Twitter; ISIS marshals supporters through Facebook. ${ }^{74}$ We might wish that such elasticity was not part of imaginative agency, but it is: devils can have good tunes too. And the good tunes can be diabolical. In a powerful critique of Facebook, John Lanchester cites a 2017 paper in the American Journal of Epidemiology on the unhealthy effects of social media: 'A 1 per 
cent increase in "likes" and clicks and status updates was correlated with a 5 to 8 per cent decrease in mental health... there is a lot of research showing that Facebook makes people feel like shit. ${ }^{75}$ In this respect, imaginative agency which effects successful action can be shackled by its own success.

\section{CONCLUSIONS}

User-generated content accounts for an increasing percentage of web content. In digital's complex entanglements of production and profitability, imaginative agency helps describe important relations between content and use without manacling them to mercantilism. 'Commercial leveraging of user-generated content such as apps, videos, or photos is a complex process, and many digital media creators and potentially valuable creations fail to realize their value in the marketplace' say McKenzie et al. (2012), adding 'UGC creates cultural, symbolic, and affective benefit including personal satisfaction, enhanced skill or reputation, improved functionality for existing games or devices, community building or civic engagement. The collaborative construction of new media products is linked with more than the creation of economic value; it is argued to be inextricably linked with civic engagement'. ${ }^{76}$ Including imaginative agency as part of the landscape would restore something lost in a language where cultural creation is relentlessly blended with wealth creation. It could also help resist appropriations of imagination to represent work as play. Microsoft's tag line, 'Where do you want to go today?', an ad campaign of 1994-5 meant to make personal computers synonymous with free exploration, was grimly wishful thinking for employees chained to their desks. For the post-millennial digital subject, work and play are hard to separate, as Rob Gallagher explains:

For Kirkpatrick (2013), videogames are a product of the shift towards a more 'ludic' model of capitalism, a shift which saw employers attempting to address growing dissatisfaction with the stultifying monotony and rigid hierarchies of the Fordist workplace by recasting work as more creative, fulfilling and flexible...The promise was of entrepreneurial individuals liberated to pursue forms of 'passionate work' suited to their abilities, interests and personal commitments (McRobbie 2016, 36). The reality, however, has been one of aggressive deskilling, greater precarity, fiercer competition and widening inequality... while 'ludic capitalism' might sound more agreeable than its forbears, it is not just about 'paidiac' playfulness and creativity but also the drive to game the system, maximize advantages and exploit rivals' weaknesses. ${ }^{77}$ 
Imaginative agency has a politics in terms of its relations to states, corporations and platforms. In 2012 Martin Zierold proposed that 'In the near future it will be decided whether commercial aspects of the use of media will have priority over cultural interests. ${ }^{, 78}$ Perhaps rather than one decisive victory there are now many struggles. Contemporary social theory has sought to get beyond dualisms, says T.V. Reed, preferring 'to speak of mutually constitutive or dialectical interactions between agency and structure' (216). Imaginative agency favours cultural interests but also promotes understanding of how, why and for whom they get monetised, so we can recognise how dialectical interactions change.

Different generations-and subjects within generations-experience media in different forms. Imaginative agency has histories which need to be part of particularising. In digital history, for instance, there was an important phase of file sharing, especially of music. It made music the stuff of sharing, shared music as a medium, and widened into sharing as a common online practice in new forms which constituted subjectivity far more than previously. Here the law protected one kind of imaginative agentproducers-against another-consumers. Though it continues the history of copyright which began in the early modern period, file sharing in the digital era introduced so many new forms of circumvention that copyright infringements became a norm. Burning CDs on your computer was normal; swapping music files with friends was normal too. Napster, appearing in 1999, promoted peer-to-peer file sharing over the internet especially of digital audio files, typically songs, in MP3 format. By 2001, it had 26.4 million users. Gradually producers regained ground: the iTunes Music Store which began in 2003 included digital rights management to prevent sharing. In the US, a Digital Millennium Copyright Act of 1998, followed by an EU Electronic Commerce Directive in 2000, further criminalised copyright violations and regulated infringements by providers. ${ }^{79}$ The big and fascinating history of file sharing can be read as a struggle between libertarian imaginations-people wanting to make their own playlists-and cultural industries (especially film and music) which need to retain control over their product lest unlicensed and unlimited reproduction of it destroy their business. Moreover, there were two kinds of agents in the industry: primary and secondary producers, the musicians and the record companies, each needing to retain their intellectual property and cultural capital. Around the millennium, open business models were debated. For some, it seemed a promising moment for imaginative agency:

it seemed entirely reasonable to have the highest expectations for music on the internet. We thought there would be explosions of wealth and of ways to become wealthy, leading to super-Gershwins. A new species of musician would be inspired to suddenly create radically new kinds of music to be 
performed in virtual worlds, or in the margins of e-books, or to accompany the oiling of fabricated robots. Even if it was not yet clear what business models would take hold, the outcome would surely be more flexible, more open, more hopeful than what has come before in the hobbled economy of physicality. ${ }^{80}$

Imaginative agents are fluidly interpellated across platforms and combinations of platforms. In digital terms, Friends Reunited (2000) and Second Life (2003) have affordances-properties relevant to how they can be used-which enable imaginative agency in different ways from successors like Facebook (2004), Twitter (2006), Pinterest (2010) and Instagram (2010). Texting, muti-media messaging and email also have distinct social affordances: the technological properties which define how each can be used have social equivalents, their changing conventions or protocols of use. Digital and media literacies move on: test this by how many current geek jokes you understand. ${ }^{81}$

Nonetheless, it is possible to imagine imagination as a key to the future:

Some of our more famous technologies, the wheel, the printing press, have changed the world and human identities in unimaginably diverse ways. So too will our digital tools, with an emphasis on the unimaginable part. The tools will only be as good as the imaginations of the people that put them to use. ${ }^{82}$

\section{ACKNOWLEDGEMENTS}

This article has been made possible as a result of funding from the European Research Council (ERC) for the project 'Ego-Media: the impact of new media on forms and practices of self-presentation' [FP7/2007-2013; grant agreement No. 340331].

\section{WORKS CITED}

1966: A Journal of Creative Nonfiction. https://1966journal.org/.

Adorno, Theodor W. The Culture Industry. London: Routledge, 1991.

alteredbarbie.com.

Aly, Anne, Stuart Macdonald, Lee Jarvis, and Thomas M. Chen, eds. "Introduction”, special issue, 'Terrorist Online Propaganda and Radicalisation." Studies in Conflict and Terrorism 40.1 (2017): 1-9.

Awad, Sarah H. "We are not free, admit it ... but we cling onto tomorrow': Imagination as a Tool for Coping in Disempowering Situations.” Eds. Brady Wagoner, Ignacio Brescó de Luna and Sarah H. Awad. The Psychology of Imagination: History, Theory and New Research Horizons. Charlotte, NC: Information Age Publishing, 2017. 267-281. 
Baraniuk, Chris. "Artificial Intelligence Invents New Styles of Art that People Like." It's Interesting 5 July 2017.

Bartlett, Jamie. The Dark Net: Inside the Digital Underworld. London: Heinemann, 2014.

Bot or Not. "What is computer poetry?" np, nd. http://botpoet.com/.

Brouillette, Sarah. Literature and the Creative Economy. Stanford: Stanford University Press, 2014.

Butler, Judith. "Performative Acts and Gender Constitution: An Essay in Phenomenology and Feminist Theory." Theatre Journal 40.4 (1988): 519-531.

Butler, Judith. "Hannah Arendt's challenge to Adolf Eichmann." The Guardian 29 August 2011.

Christodoulou, Holly. "The Hidden Web.” The Sun Online 9 March 2018.

Coleridge, Samuel Taylor. Biographia Literaria: or Biographical Sketches of My Literary Life and Opinions. (2 vols). London: Fenner, 1817.

Danesi, Marcel. The Semiotics of Emoji: The Rise of Visual Language in the Age of the Internet. London: Bloomsbury, 2016.

Davies, Dave. "How A Russian Troll Factory Waged An Aggressive Campaign To Disrupt The U.S. Election.” National Public Radio 2018.

Dhrodia, Azmina. "We tracked 25,688 abusive tweets sent to women MPs - half were directed at Diane Abbott." New Statesman 5 September 2017.

Dix, Hywel, ed. Autofiction in English. London: Palgrave Macmillan, Studies in Life Writing, 2018.

Duggan, Maeve. "Online Harassment 2017." Pew Research Center 11 July 2017.

Eggan, Matt. "What is the Dark Web and How to Access it." Tech Advisor 6 April 2018.

Erll, Astrid, and Ansgar Nünning, eds., in collaboration with Sara B. Young. A Companion to Cultural Memory Studies. Berlin: de Gruyter Verlag, 2008.

Farwell, James P. “The Media Strategy of Isis.” Survival: Global Politics and Strategy 56.6 (2014): $49-55$.

Feucht, Dennis. 'Is Technology More Advanced than it Appears?' EDN Network 20 February 2014.

Fischer, Georg, and Lorenz Grünewald-Schukalla, eds. 'Originalität und Viralität von (Internet-)Memes,' kommunikation@gesellschaft special issue on memes, 2018.

Gallagher, Rob. Videogames, Identity and Subjectivity. London: Routledge, 2017.

Gayford, Martin. "Robot Art raises Questions about Human Creativity." MIT Technology Review February 152016.

Gendler, Tamara. "Imagination." Stanford Encyclopaedia of Philosophy 2011.

Gerbaudo, Paulo. Tweets and the Streets: Social Media and Contemporary Activism. London: Pluto Press, 2012.

Gibbs, Samuel. "CES 2018: Voice-Controlled Showers, Non-Compliant Robots and Smart Toilets." The Guardian 12 January 2018.

Gillespie, Alex, Kevin Corti, Simon Evans, and Brett Heaman. "Imagining the Self Through Cultural Technologies." Eds. Vlad Glăveanu and Tania Zittoun. Handbook of Imagination and Culture. Oxford: Oxford University Press, 2017. 301-318.

Glăveanu, V. P., ed. The Palgrave Handbook of Creativity and Culture Research. London: Palgrave, 2016.

Glăveanu, Vlad Petre, Maciej Karwowski, Dorota M. Jankowska, and Constance de SaintLaurent. "Creative Imagination." Eds. Vlad Glăveanu and Tania Zittoun. Handbook of Imagination and Culture. Oxford: Oxford University Press, 2017. 61-86.

Goddard-Scovel, Eric, and Gnoetry. Same: a Stein Wreader. Np: Beard of Bees Press, 2016. http://www.beardofbees.com/pubs/same_a_Stein_wreader.pdf.

Gold, Matthew K., and Lauren F. Klein, eds. Debates in the Digital Humanities. Minneapolis: University of Minnesota Press, 2016. 
Greenberg, Andy. "Biohackers Encoded Malware in a Strand of DNA." Wired 8 October 2017. Gutkind, Lee. The Art of Creative Nonfiction: Writing and Selling the Literature of Reality. New York: John Wiley \& Sons, 1997.

Hardaker, Claire. "Trolling in Asynchronous Computer-Mediated Communication: From User Discussions to Academic Definitions." Journal of Politeness Research 6.2 (2010): 215242.

Heal, Jane. Mind, Reason and Imagination. Cambridge: Cambridge University Press, 2003.

Heinrich, Tobias. "Communicative Identity in the Eighteenth Century: Johann Wilhelm Ludwig Gleim's Epistolary Network and the Cult of Friendship." European Journal of Life Writing 3 (2014): 100-122.

Howe, Jeff. "The Rise of Crowdsourcing." Wired 6 June 2006.

Howkins, John. Creative Ecologies: Where Thinking is a Proper Job. Brisbane: University of Queensland Press, 2009.

Ioanes, Anna. "Scroll+Assemble+Repair: Reading The Argonauts." ASAP/J. 29 Nov 2018.

June, Laura. "Twitter's favorite spambot, @Horse_ebooks, hits 100k followers." The Verge 29 August 2012.

Kemeny, Richard. "Art History AI sees Links between Hundreds of Years of Paintings." New Scientist 31 January 2018.

Lamerichs, Nicolle. "Stranger than Fiction: Fan Identity in Cosplay." Transformative Works and Cultures 7 (2011).

Lanchester, John. "You are the Product." London Review of Books 39.16 (17 August 2017): $3-10$.

Lanier, Jaron. You are Not a Gadget. London: Penguin, 2011.

Latour, Bruno. "On Actor-Network Theory. A Few Clarifications Plus More Than a Few Complications." (1990) English version 1996 http://www.cours.fse.ulaval.ca/edc-65804/ latourclarifications.pdf; http://www.bruno-latour.fr/sites/default/files/P-67\%20ACTOR-NETWORK.pdf.

Lee, Peter. "Learning from Tay's Introduction." Microsoft official blog, 25 March 2016 https://blogs.microsoft.com/blog/2016/03/25/learning-tays-introduction/\#sm.00000g jdpwwcfcus11t6oo6dw79gw.

Lenoir, Timothy, and Henry Lowood. "Theatres of War: The Military-Entertainment Complex." Eds. J. Lazardzig, H. Schrann and L. Schwarte. Kunstkammer, Laboratorium, Bühne - Schauplätze des Wissens im. 17. Jahrgundert. Berlin: de Gruyter, 2003. 432-464.

Lyndsey Gilpin. "The Geekiest Tech Jokes on the Internet." Tech Republic 3 October 2014.

McKenzie, Pamela J., Jacquelyn Burkell, Lola Wong, Caroline Whippey, Samuel E. Trosow, Michael McNally. "User-Generated Online Content 1: Overview, Current State and Context." First Monday [S.1.] June 2012.

MessYourself, Chef. "How to Make a Cake - Cooking with Chef MessYourself." YouTube 8 September 2016. https:/ /www.youtube.com/watch?v=qeWI8DF-JpI.

Mithander, Conny, John Sundholm, and Adrian Velicu, eds. European Cultural Memory Post-89. Amsterdam: Rodopi, 2013.

MIX. "This Creepy Tool Reveals how Facebook's AI Tracks and Studies your Activity.” TNW2017.

Newport, Emma. "Brief Encounters: Curating GIFs, Memes and Social Media for Short Story Life-Writing." Ed. Jo Parnell. New and Unusual Ways of Writing Lives. Basingstoke: PalgraveMacMillan, forthcoming.

Onion, The. "Raytheon Unveils Military Robot Capable Of Composing Poignant Poems About Horrors Of War." 16 February 2018.

Orlowski, Andrew. "Petty PETA Rapped by Judges Over Copyright Selfie Stunt." The Register 23 April 2018.

Painting Fool. http://www.thepaintingfool.com/. 
Papacharissi, Zizi. "Without You, I'm Nothing: Performances of the Self on Twitter." International Journal of Communications 6 (2012): 1989-2006.

Pariser, Eli. "Beware Online Filter Bubbles.” TED talk, 2011.

Pearce, Graham, and Nicholas Platten. "Promoting the Information Society: The EU Directive on Electronic Commerce." European Law Journal 6 (2000): 363-378.

Priceonomics Data Studio. "Ranking the most Popular Memers on the Internet." Priceonomics n.d. https://priceonomics.com/ranking-the-most-popular-memers-on-the-internet.

Rahman, Osmud, Liu Wing-Sun, Brittany Hei-man Cheun. "Cosplay': Imaginative Self and Performing Identity." Fashion Theory 16.3 (2010): 317-341.

Reed, T. V. Digitized Lives: Culture, Power and Social Change in the Internet Era. London: Routledge, 2014

Rubin, Ben Fox. "Alexa, Google Assistants Want to be Everywhere in 2018." C/Net 16 January 2018.

Scarry, Elaine. The Body in Pain: The Making and Unmaking of the World. Oxford: Oxford University Press, 1988.

Schellenberg, Betty A. Literary Coteries and the Making of Modern Print Culture: 1740-1790. Cambridge: Cambridge University Press, 2016.

Schep, Dennis. "The Limits of Performativity: A Critique of Hegemony in Gender Theory." Hypatia: A Journal of Feminist Philosophy 27.4 (2012): 864-880.

Schlesinger, Philip. "The Creative Economy: Invention of a Global Orthodoxy." 11 December 2015. http://blogs.lse.ac.uk/mediapolicyproject/2015/12/11/the-creative-economy-invention-of-a-global-orthodoxy/.

Schneier, Matthew. "Mary Beard and her 'Battle Cry' Against Internet Trolling." New York Times 16 April 2016.

Schubert Rikke, Fabian Virchow, Debra White-Stanley and Tanja Thomas, eds. War isn't Hell, It's Entertainment: Essays on Visual Media and the Representation of Conflict. Jefferson, NC: McFarland, 2009.

Scougal, Will. "Somewhere Over the Rainbow." Metro 7 March 2018.

Segarra, Lisa Marie. "Everyone Loves these Penguins who have a Better Selfie Game than you do." Time Magazine 9 March 2018.

Smith, Sidonie, and Julia Watson. "Virtually Me: A Toolbox about Online Self-Presentation." (2014) Life Writing in the Long Run: A Smith E् Watson Autobiography Studies Reader. Ann Arbor, MI: Michigan Publishing, University of Michigan Library, 2017.

Sommer, Doris, ed. Cultural Agency in the Americas. Durham, NC: Duke University Press, 2006.

Sontag, Susan. Regarding the Pain of Others. NY: Picador, 2003.

Stahl, Roger. Militainment, Inc.: War, Media, and Popular Culture. NY: Routledge, 2010. https:// staysafeonline.org/data-privacy-day/.

Stevenson, L. "Twelve Conceptions of Imagination." British Journal of Aesthetics 43.3 (2003): 238-259.

Treanor, Brian, and Henry Isaac Venema. A Passion for the Possible: Thinking with Paul Ricoeur. New York: Fordham University Press, 2010.

Trotter, David. Cooking with Mud: The Idea of Mess in Nineteenth-Century Art and Fiction. Oxford: Oxford University Press, 2000.

Turton, William. "How YouTube's Algorithm Prioritizes Conspiracy Theories." Vice News 6 March 2018.

Wagner-Egelhaaf, Martina, ed. Autobiography/Autofiction. An International and Interdisciplinary Handbook, 3 vols. Berlin: de Gruyter Verlag, 2018.

Wagoner, Brady, Ignacio Brescó de Luna, and Sarah H. Awad, eds. The Psychology of Imagination: History, Theory and New Research Horizons. Charlotte: NC: Information Age Publishing Inc, 2017.

Walters, Joanna. "Steve Bannon on Cambridge Analytica." The Guardian 22 March 2018. 
Waugh, Rob. 'YouPorn's AI has Predicted the Future of Porn, from 'Mature Gargasm' to 'Tang Pong'." Metro 7 March 2018.

Winter, Chase. "Almost a Quarter of Women Experience Online Abuse and Harassment." DW 20 November 2017.

Wong, Julia Carrie. "Monkey Selfie Photographer says he's Broke: 'I'm Thinking of Dog Walking'." The Guardian 13 July 2017.

Zierold, Martin. "Memory and Media Cultures." Eds. Astrid Erll and Ansgar Nünning in collaboration with Sara B. Young. A Companion to Cultural Memory Studies. Berlin: de Gruyter Verlag, 2008. 398-407.

Zittoun, Tania, and Alex Gillespie. "Imagination: Creating Alternatives in Everyday Life." Ed. Vlad Petre Glăveanu. The Palgrave Handbook of Creativity and Culture Research. London: Palgrave, 2016. 225-242.

Zittoun, Tania, and Vlad Glăveanu, eds. Handbook of Imagination and Culture. Oxford: Oxford University Press, 2017.

Zylinska, Joanna. Nonhuman Photography. Cambridge, MA: MIT Press, 2017.

\section{ABOUT THE AUTHOR}

Clare Brant is Professor of Eighteenth-Century Literature and Culture at King's College London where she also co-directs the Centre for Life-Writing Research. She has published widely (and hopefully deeply) on literature, culture and gender. Her most recent book was Balloon Madness: Flights of Imagination in Britain, 1783-1786 (Boydell 2017). She co-edits the Palgrave series Studies in Life Writing, and is an editor on the European Journal of Life Writing. She was a Co-Investigator on the European Research Council-funded Ego Media project at KCL (2014-2019). Her fourth collection of poems will be published by Shoestring Press in 2020. Email: clare.brant@kcl.ac.uk

\section{NOTES}

1 On autofiction see Wagner-Egelhaaf 2018 and Dix 2018.

2 In tandem with a forthcoming Ego Media publication in which I aim to explore imaginative agency further through a range of case studies.

3 See Erll and Nünning 2008.

4 Gendler 2011. "Imagination".

5 Stevenson (2003) has an abstract on St Andrew's research portal summarising the taxonomy thus: (1) The ability to think of something not presently perceived, but spatiotemporally real. (2) The ability to think of whatever one acknowledges as possible in the spatio-temporal world. (3) The liability to think of something that the subject believes to be real, but which is not. (4) The ability to think of things that one conceives of as fictional. (5) The ability to entertain mental images. (6) The ability to think of anything at all. (7) The non-rational operations of the mind, that is, those explicable in terms of causes rather than reasons. (8) The ability to form perceptual beliefs about public objects in space and time. (9) The ability to sensuously appreciate works of art or objects of natural beauty without classifying them under concepts or thinking of them as useful. (10) The ability to create works of art that encourage such sensuous appreciation. 
(11) The ability to appreciate things that are expressive or revelatory of the meaning of human life. (12) The ability to create works of art that express something deep about the meaning of life. https://risweb.standrews.ac.uk/portal/en/researchoutput/twelveconceptions-of-imagination(91123843-0fb7-4dc9-a049-1a61d80d8124).html, accessed 30 December 2017.

6 Gendler 2011.

7 See Treanor and Venema 2010.

8 Danesi 2016.

9 Smith and Watson 2017, n.p.

10 Heal 2003.

11 http://www.sharethis.com/usage/.

12 Butler 1988; also Schep, 2012.

13 Papacharissi 2012.

14 Awad 2017, 268.

15 See Brouillette 2014, especially ch. 3, 56-82.

16 See Trotter 2000, and the surprisingly popular Chef MessYourself.

17 Priceonomics n.d., https://priceonomics.com/ranking-the-most-popular-memers-onthe-internet. See also Fischer and Grünewald-Schukalla 2018.

18 For memes as imaginative catalysts, see Newport, forthcoming.

19 Schlesinger 2015.

20 Idem and http://www.creativeeconomy.com/john.htm.

21 Gutkind 1997; see also 1966: A Journal of Creative Nonfiction.

22 Compare the critique of cultural industry in Adorno 1991.

23 See Mithander, Sundholm and Veliku 2013.

24 Howkins 2009.

25 Sommer 2006, 4-6.

26 Latour, 1996; http://www.bruno-latour.fr/sites/default/files/P-67\%20ACTOR-NETWORK.pdf.

27 Smith and Watson 2014.

28 Schellenberg 2016, 94.

29 Heinrich 2014, 100-122.

30 https://blog.singularitynet.io/singularitynet-integrates-aigents-social-intelligenceservices-creating-significant-first-mover-a4f3bf6bef3 20/02/18; https://blog.singularitynet.io/hacken-joins-singularitynet-to-pursue-ai-powered-cybersecuritya241e373e7b7, accessed 20 February 2018.

31 https://www.hansonrobotics.com/sophia/. Accessed 29 January 2019. See also https:// en.wikipedia.org/wiki/Sophia_(robot). Accessed 20 February 2018.

32 Lee 2016.

33 Gibbs 2018.

34 Fox Rubin, 2018.

35 See also Zylinska 2017.

36 Gayford 2016.

37 Kemeny 2018; Baraniuk 2017.

38 The Onion, 2018. Grateful thanks to Rebecca Roach for this reference.

39 http://botpoet.com/what-is-computer-poetry/ accessed 18 February 2018. Thanks again to Rebecca Roach for alerting me to this material.

40 June, 2012.

41 Goddard-Scovel and Gnoetry 2016.

42 http://www.thepaintingfool.com/; accessed 26 February 2018.

43 Wong 2018. On the final ruling in a ruined Slater's favour, see Orlowski 2018. See also emperor penguin selfies in 2018: Segarra 2018. 
44 Waugh 2018.

45 For a very productive instance, see Anna Ioanes' reading of Maggie Nelson's The Argonauts: Ioanes 2018. My thanks to the anonymous reviewer for $E J L W$ for this reference.

46 Scarry 1988, 27.

47 Sontag 2003, 38.

48 Idem 77, 82, 98.

49 Winter 2017; Duggan 2017.

50 Bartlett 2014, 30.

51 Idem 29.

52 Davies 2018.

53 Andrew Finch, killed in Wichita, Kansas, 25 December 2017, https://www.vox.com/ policy-and-politics/2018/1/13/16888710/barris-swatting-death-charges. Accessed 21 January 2018.

54 On trolling, see Hardaker 2010, 215-42.

55 'A bit of outrage is good, but having your only rhetorical register as outrage is always going to be unsuccessful. You've got to vary it. Sometimes, some of the things that sexist men do just deserve to be laughed at.' Schneier 2016.

56 Dhrodia 2017.

57 Butler 2011.

58 Greenberg 2017.

59 Eggan 2018.

60 Christodoulou 2018.

61 Feucht 2014.

62 Lenoir and Lowood 2003, 432-64, 432. See also Schubert et al. 2009.

63 Stahl 2010.

64 https://staysafeonline.org/data-privacy-day/.

65 Turton 2018.

66 Pariser 2011.

67 MIX 2017.

68 Walters 2018; by April the figure had been revised up to 87 million. Facebook's response is at https://newsroom.fb.com/news/2018/04/restricting-data-access/.

69 Howe 2006.

70 My thanks to Katherine Armstrong and her novel The Odd Child.

71 Scougal 2018.

72 See for example alteredbarbie.com.

73 Gerbaudo 2012, 3.

74 Farwell 2014, 49-55; Aly et al. 2017, 1-9.

75 Lanchester 2017, 3-10.

76 McKenzie et al., 2012.

77 Gallagher 2018, 5.

78 Zierold 2012, 398-407, 405.

79 Pearce and Platten 2000, 363-378.

80 Lanier 2011, 128.

81 e.g. Gilpin 2014.

82 Reed 2014, 5. My thanks to Max Saunders for this reference. And thanks to all the Ego Media research group for helping to inform my thinking. 